\title{
Article
}

\section{Zeolite Composite Nanofiber Mesh for Indoxyl Sulfate Adsorption toward Wearable Blood Purification Devices}

\author{
Makoto Sasaki ${ }^{1,2}$, Yihua Liu ${ }^{1}$ (D) and Mitsuhiro Ebara ${ }^{1,2,3, * \mathbb{D}}$ \\ 1 Research Center for Functional Materials (RCFM), National Institute for Materials Science (NIMS), \\ Tsukuba 305-0044, Japan; s2020340@s.tsukuba.ac.jp (M.S.); liu.yihua@nims.go.jp (Y.L.) \\ 2 Degree Programs in Pure and Applied Sciences, University of Tsukuba, Tsukuba 305-8577, Japan \\ 3 Graduate School of Advanced Engineering, Tokyo University of Science, Tokyo 125-8585, Japan \\ * Correspondence: ebara.mitsuhiro@nims.go.jp; Tel.: +81-29-860-4775
}

Citation: Sasaki, M.; Liu, Y.; Ebara, M. Zeolite Composite Nanofiber Mesh for Indoxyl Sulfate Adsorption toward Wearable Blood Purification Devices. Fibers 2021, 9, 37.

https://doi.org/10.3390/fib9060037

Academic Editors: Sanjib

C. Chowdhury and

Subramani Sockalingam

Received: 24 March 2021

Accepted: 28 May 2021

Published: 3 June 2021

Publisher's Note: MDPI stays neutral with regard to jurisdictional claims in published maps and institutional affiliations.

Copyright: (c) 2021 by the authors. Licensee MDPI, Basel, Switzerland. This article is an open access article distributed under the terms and conditions of the Creative Commons Attribution (CC BY) license (https:// creativecommons.org/licenses/by/ $4.0 /)$.

\begin{abstract}
A nanofiber mesh was prepared for the adsorption of indoxyl sulfate (IS), a toxin associated with chronic kidney disease. Removing IS is highly demanded for efficient blood purification. The objective of this study is to develop a zeolite composite nanofiber mesh to remove IS efficiently. Eight zeolites with different properties were used for IS adsorption, where a zeolite with a pore size of $7 \AA, \mathrm{H}^{+}$cations, and a silica to aluminum ratio of $240 \mathrm{~mol} / \mathrm{mol}$ exhibited the highest adsorption capacity. This was primarily attributed to its suitable silica to aluminum ratio. The zeolites were incorporated in biocompatible poly (ethylene-co-vinyl alcohol) (EVOH) nanofibers, and a zeolite composite nanofiber mesh was successfully fabricated via electrospinning. The nanofiber mesh exhibited an IS adsorption capacity of $107 \mu \mathrm{g} / \mathrm{g}$, while the adsorption capacity by zeolite increased from $208 \mu \mathrm{g} / \mathrm{g}$ in powder form to $386 \mu \mathrm{g} / \mathrm{g}$ when dispersed in the mesh. This also led to an increase in cell viability from $86 \%$ to $96 \%$. These results demonstrated that this zeolite composite nanofiber mesh can be safely and effectively applied in wearable blood purification devices.
\end{abstract}

Keywords: chronic kidney disease; uremic toxin; hemodialysis; indoxyl sulfate; nanofibers; electrospinning

\section{Introduction}

Various uremic toxins accumulate in the blood of patients with chronic kidney disease (CKD), which can lead to complications, such as anemia [1,2], cardiovascular disease [3], hyperkalemia [4], and even death in severe cases [5]. The main treatment for CKD is hemodialysis, where uremic toxins are removed from the blood via ultrafiltration and/or diffusion. However, indoxyl sulfate (IS) is a protein-bound uremic toxin that cannot be easily removed via hemodialysis.

Specifically, hemodialysis is capable of removing IS at a rate of 25 to $30 \mathrm{~mL} / \mathrm{min}$, which is only $10 \%$ of the clearance for free and small uremic toxins in urea [6]. Approximately $90 \%$ of IS in serum is bound to albumin, and these large bound particles cannot pass through the dialysis membrane [7]. IS can reportedly accelerate the progression of CKD [8,9] and induce cardiovascular disease, osteoporosis, and anemia $[10,11]$. Therefore, the removal of IS from the blood of CKD patients is essential for effective blood purification, and a novel method for improved treatment is required.

As a new method of IS removal, we focused on the adsorption of IS by zeolite. Zeolite is a promising adsorbent of IS and is an inorganic substance expressed as $\mathrm{M}^{\mathrm{n}+}{ }_{\mathrm{x} / \mathrm{n}} \mathrm{Al}_{\mathrm{x}} \mathrm{Si}_{\mathrm{y}} \mathrm{O}_{2 \mathrm{x}+2 \mathrm{y}}{ }^{\mathrm{x}-} \cdot \mathrm{zH}_{2} \mathrm{O}$. It has a porous structure, and is often used as a catalyst, molecular sieve, and adsorbent [12-14]. Synthetic zeolites have been actively researched as an alternative to natural zeolites [15,16], as synthetic zeolites offer a uniform structure or composition, such as pore size, $\mathrm{Si} / \mathrm{Al}$ ratio, and particle size, and allow for the selective adsorption of target molecules [17].

Therefore, an appropriate synthetic zeolite shows promise for the selective adsorption of waste products (e.g., uremic toxins and electrolytes) from the blood of CKD patients, 
while remaining inert substances that should not be removed (e.g., amino acid and vitamin). Some studies showed that zeolite effectively adsorbs several uremic toxins, including a $p$-cresol and creatinine $[18,19]$. However, the toxicity of zeolites has limited their applications within the human body. To prevent the outflow of zeolite, membranes made of polyethersulfone or cellulose acetate have been used in some studies [20,21].

In this study, we focused on nanofibers because they have a larger surface area compared to membranes and, thus, more efficient adsorption of uremic toxins is expected. The incorporation of zeolites in biocompatible nanofibers can also improve the IS adsorption capacity by preventing them from aggregation. Therefore, we immobilized them within a poly(ethylene-co-vinyl alcohol) (EVOH) nanofiber mesh to improve the biocompatibility of zeolites and prevent outflow. EVOH is commonly used as a hemodialysis membrane due to its blood compatibility and biocompatibility; thus, the immobilization on an EVOH nanofiber mesh is expected to reduce the toxicity of zeolites because it can prevent zeolites from direct interaction with blood cells [22,23].

Our previous studies have demonstrated the use of a nanofiber mesh system for the selective adsorption of creatinine and water in blood using zeolite/EVOH and poly(sodium acrylate), respectively [24-26]. This system does not rely on advanced healthcare infrastructure, and is a practical solution in disaster scenarios or in developing countries without high-level hemodialysis equipment. In this report, we focus on the development of a nanofiber mesh for the adsorption of IS.

These mesh materials were fabricated via electrospinning, which is a conventional method for the preparation of nanofibers [27]. Nanofibers offer a larger surface area, smaller weight, and mesh size compared with microfibers, and have been widely applied in medical fields, such as tissue engineering, drug delivery, and wound dressings [28-30]. In addition, X. Yu et al. fabricated a polyacrylonitrile nanofiber for the efficient removal of middle-molecule uremic toxins [31]. The core-shell nanofiber consisted of polyethersulfone (core) and polyvinylpyrrolidone, and a zeolite (shell) was also produced by F. Haghdoost et al. for creatinine adsorption [32]. However, to our best knowledge, a nanofiber for IS adsorption has not yet been reported.

This study aimed to develop a nanofiber mesh to facilitate IS adsorption filters toward a wearable blood purification device. The important properties of various zeolites for IS adsorption were investigated, and a zeolite/EVOH nanofiber mesh was produced via electrospinning. In addition, the optimum zeolite contents and morphologies were investigated since the dispersion/aggregation state significantly affects the adsorption capacity.

\section{Materials and Methods}

\subsection{Materials}

EVOH copolymer Soarnol V2504RB with $25 \mathrm{~mol} \%$ ethylene was purchased from Mitsubishi Chemical (Tokyo, Japan). The high silica zeolite (HSZ) series of eight zeolites, namely $320 \mathrm{HOA}, 500 \mathrm{KOA}, 640 \mathrm{HOA}, 690 \mathrm{HOA}, 720 \mathrm{KOA}, 840 \mathrm{HOA}, 940 \mathrm{HOA}$, and $980 \mathrm{HOA}$, were purchased from Tosoh (Tokyo, Japan). All zeolites had a pore size similar to the molecular size of IS ( $8 \AA$ ). The zeolites are abbreviated as $X H($ or $K) Y$, where $X$ is the pore size $(\AA), \mathrm{H}$ (or K) is the cation type (proton or potassium), and $Y$ is the $\mathrm{Si} / \mathrm{Al}$ mol ratio. 3-Indoxyl sulfate potassium salt was purchased from Carbosynth (Berkshire, UK), and IS assay kits were purchased from NIPRO (Osaka, Japan).

Human Serum Albumin (HSA) was purchased from Nacalai Tesque (Kyoto, Japan). An albumin assay kit was purchased from Funakoshi (Tokyo, Japan). 1,1,1,3,3,3-Hexafluoro2-propanol (HFIP) was purchased from Tokyo Chemical Industry (Tokyo, Japan). alamarBlue ${ }^{\circledR}$ was purchased from Thermo Fisher Scientific (Waltham, MA, USA). Raw 264.7 cells were purchased from InvivoGen (CA, USA). Dulbecco's modified Eagle's medium (DMEM) was purchased from Sigma-Aldrich (St. Louis, MO, USA). 


\subsection{IS Adsorption}

IS was dissolved in distilled water to prepare a $3 \mathrm{mg} / \mathrm{dL}$ IS aqueous solution, which is comparable to the IS concentration in the blood of patients with CKD. The prepared IS aqueous solution $(10 \mathrm{~mL} ; 3 \mathrm{mg} / \mathrm{dL})$ and one of the eight different zeolites $(50 \mathrm{mg})$ were added to $20-\mathrm{mL}$ sample bottles and shaken at $37^{\circ} \mathrm{C}$ for $24 \mathrm{~h}$ in a water bath shaker (PERSONAL-11, Taitec, Saitama, Japan). The zeolite was precipitated via centrifugation at $3500 \mathrm{rpm}$ for $10 \mathrm{~min}$, and the supernatant $(8 \mu \mathrm{L})$ was collected.

The IS concentration of the supernatant was determined using an IS assay kit, which involved the addition of WST- 8 substrate and sulfatase to the supernatant and measurement of absorbance at $450 \mathrm{~nm}$ using an absorbance plate reader (Infinite M Nano+, TECAN, Männedorf, Switzerland). The IS adsorption capacity of the zeolites was calculated based on the initial IS concentration. The IS adsorption capacity of the nanofiber mesh was determined using the same method.

\subsection{Fabrication of Zeolite/EVOH Nanofiber Mesh}

Zeolite 7H240 exhibited the highest adsorption capacity for IS among the eight zeolites, and was used to prepare the zeolite-immobilized EVOH nanofiber mesh. EVOH was dissolved in HFIP at a concentration of $7 \mathrm{w} / \mathrm{v} \%$ via ultrasonication for $1 \mathrm{~h}$. The zeolite was added to the EVOH solution, and the mixture was dispersed via ultrasonication for $1 \mathrm{~h}$. Four zeolite concentrations were investigated, namely 10, 20, 30, and $40 \mathrm{wt} \%$.

Nanofibers were prepared from the dispersed $7 \mathrm{H} 240$ zeolite/EVOH solution via electrospinning at an electrospinning voltage of $25 \mathrm{kV}$, feed rate of $1.0 \mathrm{~mL} / \mathrm{h}$, distance between collectors of $15 \mathrm{~cm}$, and needle size of $22 \mathrm{G}$ (NANON-01A, MECC, Fukuoka, Japan). The obtained nanofiber mesh was dried in an oven overnight at $60^{\circ} \mathrm{C}$.

\subsection{Characterization of Zeolite/EVOH Nanofiber Mesh}

The morphology of the 7H240 zeolite/EVOH nanofiber mesh was observed in $\mathrm{Au}$ sputtered samples using scanning electron microscopy (SEM; JCM-5000, JEOL, Tokyo, Japan). The diameters of the nanofibers and zeolite aggregates were measured using image analysis software (ImageJ). The zeolite content of the mesh was determined using thermogravimetric analysis (TGA) in a temperature range of 25 to $500{ }^{\circ} \mathrm{C}$ at $10^{\circ} \mathrm{C} / \mathrm{min}$ (TG/DTA6200, Hitachi High-Tech Science, Tokyo, Japan). The samples were held at $500{ }^{\circ} \mathrm{C}$ for $30 \mathrm{~min}$ to completely burn the EVOH nanofibers. An HSA adsorption test was conducted in PBS solution with $4.8 \mathrm{~g} / \mathrm{dL}$. Samples of $5 \mathrm{mg}$ were immersed in the HSA solution $(1 \mathrm{~mL})$ and shaken at $37^{\circ} \mathrm{C}$ for $24 \mathrm{~h}$ in a water bath shaker (PERSONAL-11). After that, the HSA concentration was measured by the albumin assay kit.

\subsection{Cytotoxic Assays}

A cytotoxic assay of zeolite was conducted using the alamarBlue ${ }^{\circledR}$ assay. Raw 264.7 cells (murine macrophages) were seeded on 96-well cell culture plates at $1.7 \times 10^{5}$ cells/well in $0.2 \mathrm{~mL}$ high glucose DMEM supplemented with $10 \%$ fetal bovine serum (FBS), $1 \%$ L-glutamine, and $1 \%$ penicillin streptomycin. Zeolite was added $(0.5,1.0,1.5,2.0$, and $5.0 \mathrm{mg}$ ), and the culture systems were incubated at $37^{\circ} \mathrm{C}$ for $24 \mathrm{~h}$. The cell viability of each well was determined using the alamarBlue ${ }^{\circledR}$ assay, where the fluorescence was measured at an excitation wavelength of $570 \mathrm{~nm}$ and a fluorescence wavelength of $600 \mathrm{~nm}$ (Infinite M Nano+).

A cytotoxic assay of the $7 \mathrm{H} 240$ zeolite/EVOH nanofiber mesh was also conducted. Raw 264.7 cells were seeded on 24 -well cell culture plates at $1 \times 10^{6}$ cells/well in $1 \mathrm{~mL}$ of the same medium using for the cytotoxic assay of zeolite. The nanofiber mesh was added (10 $\mathrm{mg}$ nanofiber mesh with 0 or $10 \mathrm{wt} \%$ zeolite). The same procedure used for the zeolite cytotoxic assay was conducted to determine the cell viability. 


\section{Results}

\subsection{IS Adsorption Capacity of Bare Zeolite}

Eight types of zeolites with different pore sizes, cation types, and $\mathrm{Si} / \mathrm{Al}$ ratios were investigated for IS adsorption (Table 1). Zeolite 7H240 exhibited the highest adsorption capacity for IS (Figure 1a). The factors affecting the IS adsorption capacity were further investigated by evaluating the effects of the $\mathrm{Si} / \mathrm{Al}$ ratio (Figure $1 \mathrm{~b}$ ), pore size (Figure 1c), and cation type.

(a)

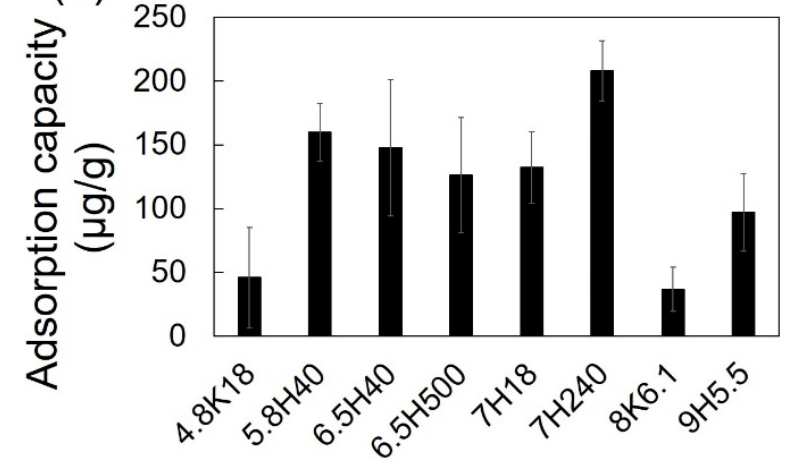

(b)

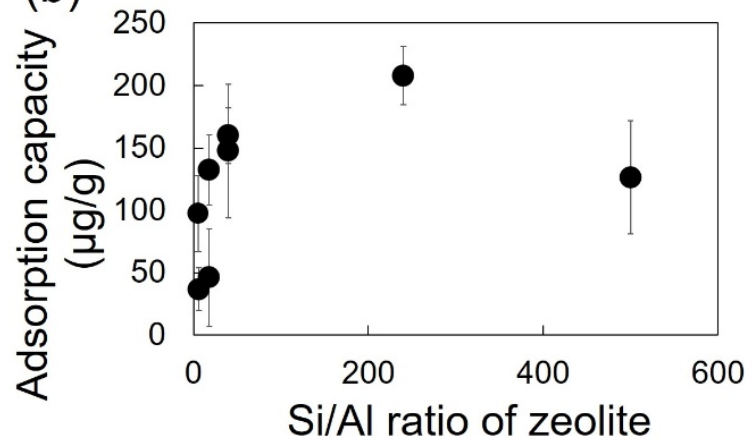

(c)

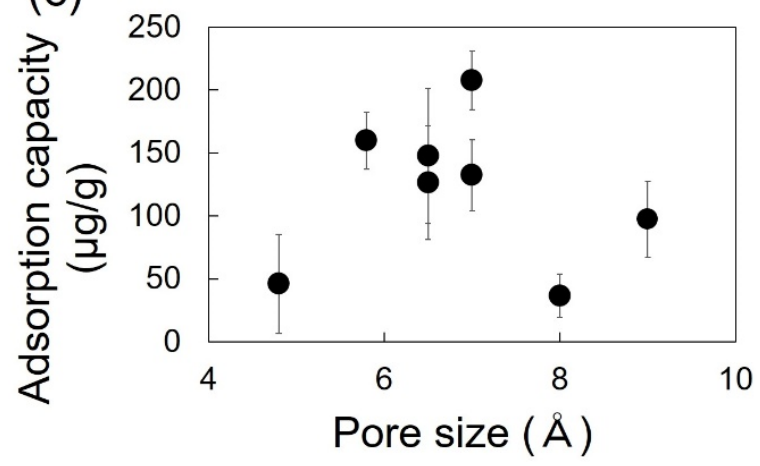

Figure 1. (a) The IS adsorption capacities of various zeolites after the $24 \mathrm{~h}$ adsorption test. (b) The IS adsorption capacities with the $\mathrm{Si} / \mathrm{Al}$ ratios of each zeolite. The high $\mathrm{Si} / \mathrm{Al}$ ratio indicates the large hydrophobicity of zeolite. (c) The IS adsorption capacities with the pore sizes of each zeolite. $(n=3)$.

Figure $1 \mathrm{~b}$ shows that the IS adsorption capacity increased with the increasing $\mathrm{Si} / \mathrm{Al}$ ratio up to $240 \mathrm{~mol} / \mathrm{mol}$. Zeolites with pore sizes between 6 and $7 \AA$ exhibited the highest adsorption capacities (Figure 1c). In addition, zeolites with a hydrogen ion as the cation exhibited a higher adsorption capacity than those with a potassium ion. As a result, zeolite 7H240 showed the highest adsorption capacity and was used for immobilization on the 
nanofiber mesh. The adsorption capacity of zeolite $7 \mathrm{H} 240$ equilibrium was within $1 \mathrm{~h}$ (Figure S1).

Table 1. The structure and composition of the eight types of zeolite used in this report.

\begin{tabular}{|c|c|c|c|c|c|c|c|c|}
\hline $\begin{array}{l}\text { Zeolite } \\
\text { Samples }\end{array}$ & $\begin{array}{l}\text { Pore Size } \\
\text { (A) }\end{array}$ & Cation & $\begin{array}{l}\text { Si/Al Ratio } \\
\text { (mol/mol) }\end{array}$ & $\begin{array}{c}\text { Surface Area } \\
\left(\mathrm{m}^{2} / \mathrm{g}\right)\end{array}$ & $\begin{array}{c}\text { Crystal } \\
\text { Size }(\mathrm{mm})\end{array}$ & $\begin{array}{c}\text { Particle } \\
\text { Size }(\mathrm{mm})\end{array}$ & $\begin{array}{l}\text { Structure } \\
\text { Type }\end{array}$ & $\begin{array}{c}\text { Product } \\
\text { Name }\end{array}$ \\
\hline 9H5.5 & 9.0 & $\mathrm{H}^{+}$ & 5.5 & 550 & 0.3 & 7 & Y-type & $320-\mathrm{HOA}$ \\
\hline $8 \mathrm{~K} 6.1$ & 8.0 & $\mathrm{~K}^{+}$ & 6.1 & 290 & 0.4 & 4 & L-type & 500-KOA \\
\hline $7 \mathrm{H} 18$ & 7.0 & $\mathrm{H}^{+}$ & 18 & 380 & 0.5 & 12 & Mordenite & $640-\mathrm{HOA}$ \\
\hline $7 \mathrm{H} 240$ & 7.0 & $\mathrm{H}^{+}$ & 240 & 450 & 0.5 & 12 & Mordenite & 690-HOA \\
\hline $4.8 \mathrm{~K} 18$ & 4.8 & $\mathrm{~K}^{+}$ & 18 & 170 & 1 & 20 & Ferierite & $720-\mathrm{KOA}$ \\
\hline $5.8 \mathrm{H} 40$ & 5.8 & $\mathrm{H}^{+}$ & 40 & 330 & 4 & 10 & ZSM-5 & 840-HOA \\
\hline $6.5 \mathrm{H} 40$ & 6.5 & $\mathrm{H}^{+}$ & 40 & 530 & 0.75 & 4 & Beta & 940-HOA \\
\hline $6.5 \mathrm{H} 500$ & 6.5 & $\mathrm{H}^{+}$ & 500 & 500 & 0.75 & 2.5 & Beta & 980-HOA \\
\hline
\end{tabular}

\subsection{Characterization of Zeolite/EVOH Nanofiber Mesh}

The plain EVOH nanofiber mesh and 7H240 zeolite/EVOH nanofiber mesh fabricated via electrospinning were observed using SEM (Figure 2a). The EVOH nanofibers were smooth and exhibited no bead structure without the added zeolite. After the incorporation of zeolite at 10 and $20 \mathrm{wt} \%$, well-dispersed zeolite particles were observed (Figure 2b,c). However, the zeolite particles began to aggregate at concentrations of 30 and $40 \mathrm{wt} \%$ (Figure 2d,e).

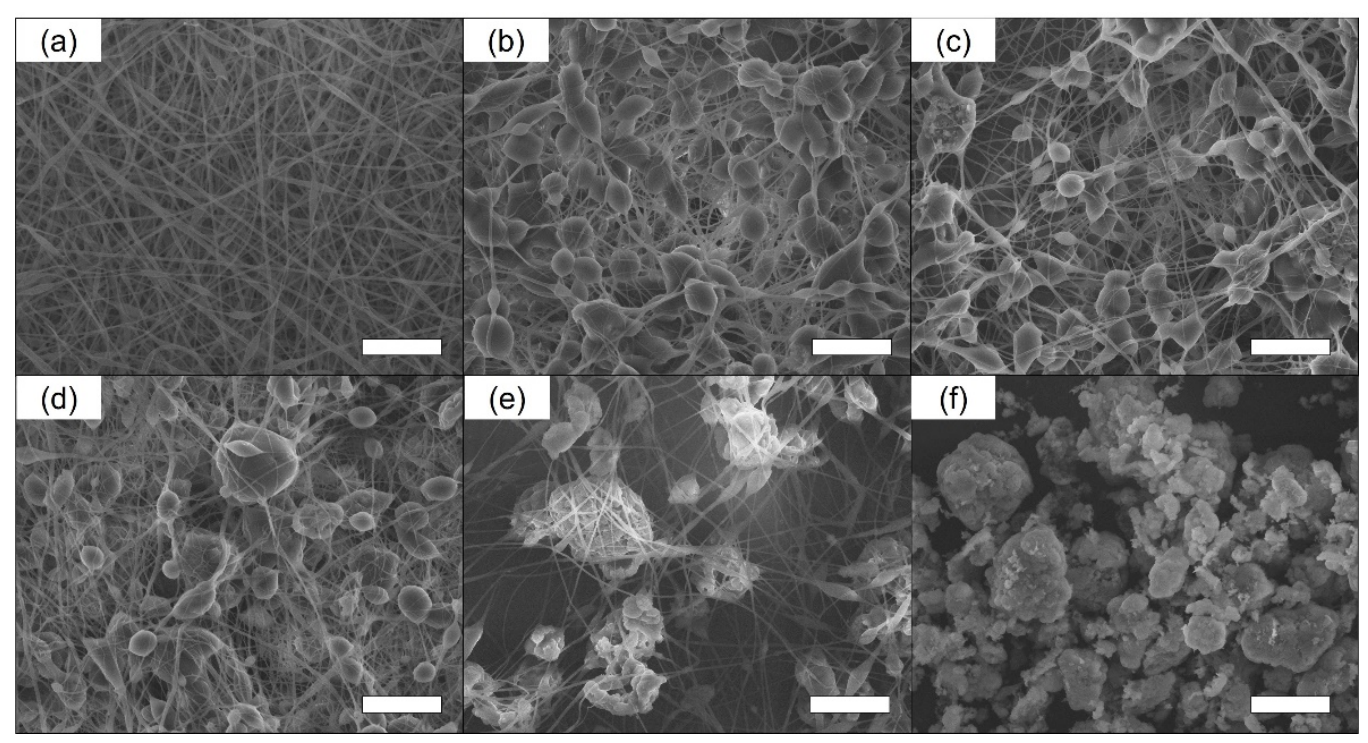

Figure 2. (a-e) SEM images of the 7H240 zeolite/EVOH nanofiber mesh at zeolite concentrations of (a) 0, (b) 10, (c) 20, (d) 30, and (e) $40 \mathrm{wt} \%$. (f) SEM image of zeolite $7 \mathrm{H} 240$ powder. Scale bar: $20 \mu \mathrm{m}$.

The diameter of the zeolite particles, nanofibers, and aggregates were calculated from the SEM images. The diameter of the zeolite 7H240 particles $(12 \mu \mathrm{m})$ was larger than that of the EVOH nanofiber $(630 \mathrm{~nm})$; thus, the zeolite $7 \mathrm{H} 240$ particles covered by the $\mathrm{EVOH}$ polymer were fixed within the nanofiber mesh. The diameter of the 7H240 zeolite/EVOH nanofibers was $\sim 450 \mathrm{~nm}$ (Figure 3a). The fiber diameter of the zeolite composite nanofiber mesh was successfully maintained between 430 and $470 \mathrm{~nm}$. As the diameter of the zeolite 7H240 particles was $\sim 12 \mu \mathrm{m}$, particles in the nanofiber mesh with diameters larger than $20 \mu \mathrm{m}$ were considered zeolite aggregates. The nanofiber mesh with $40 \mathrm{wt} \%$ zeolite exhibited the highest number of $>20 \mu \mathrm{m}$ aggregates (Figure $3 \mathrm{~b}$ ). To avoid these large aggregates, only nanofiber meshes with 0 to $30 \mathrm{wt} \%$ zeolite were investigated further. 
(a)

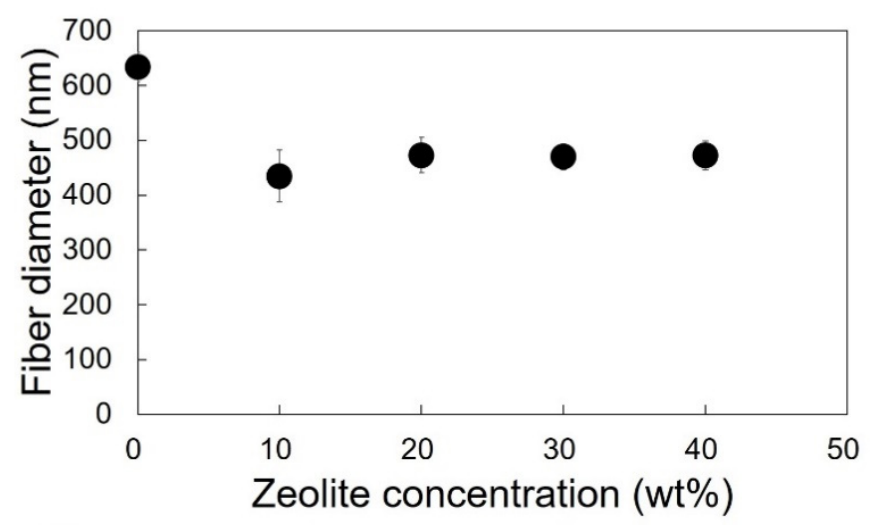

(b)

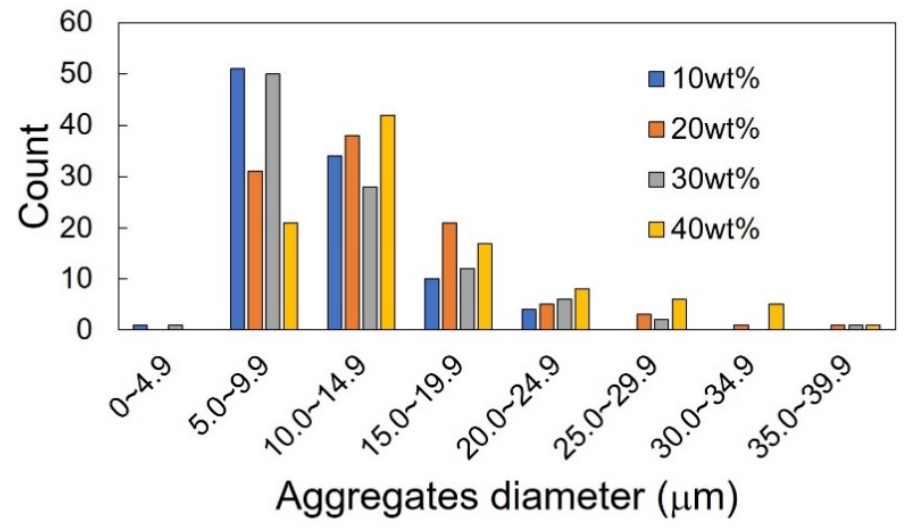

(c)

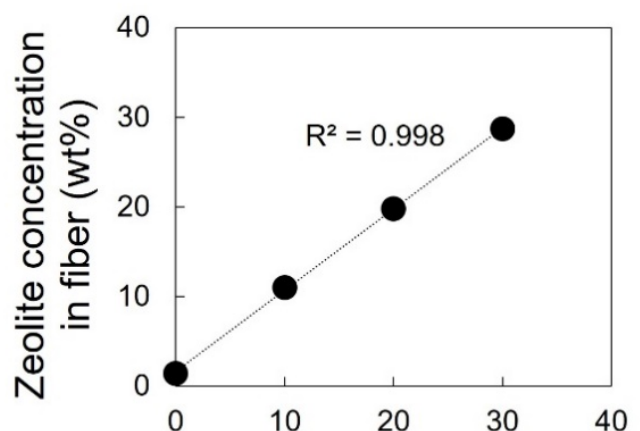

Zeolite concentration in feed ( $w t \%)$

Figure 3. (a) Fiber diameters of the electrospun $7 \mathrm{H} 240$ zeolite/EVOH at 0 to $40 \mathrm{wt} \%$ zeolite from SEM images $(n=40)$. (b) Diameters of the zeolite aggregates in the electrospun $7 \mathrm{H} 240$ zeolite/EVOH nanofiber mesh from SEM images $(n=100)$. The zeolite concentrations are 10 (blue), 20 (orange), 30 (grey), and $40 \mathrm{wt} \%$ (yellow). (c) The zeolite concentration of the electrospun 7H240 zeolite/EVOH nanofiber mesh according to TGA $(n=3)$. The $\mathrm{x}$ axis shows the zeolite concentrations in the feed before electrospinning.

The zeolite concentrations of the $7 \mathrm{H} 240$ zeolite/EVOH nanofiber mesh were determined using TGA, where the EVOH nanofibers were sublimated during heating to leave only the zeolite. Therefore, the zeolite concentration was based on the residual weight ratio of each sample. The zeolite concentrations of the nanofiber mesh corresponded closely with the concentration of the feed, and a linear relationship was observed (Figure 3c). 
Additionally, an albumin adsorption test was conducted, and no significant difference was confirmed in the albumin concentration between before and after the test for $24 \mathrm{~h}$ (Figure S2).

\subsection{IS Adsorption Test of the Zeolite/EVOH Nanofiber Mesh}

The IS adsorption of the 7H240 zeolite/EVOH nanofiber mesh increased with the increasing zeolite concentration (Figure 4a), which indicated that IS adsorption was attributed to the zeolite component of the composite mesh. The white circle in Figure 4a shows the IS adsorption capacity of zeolite $7 \mathrm{H} 240$ by zeolite mass. The IS adsorption capacity of zeolite 7H240 was relatively unaffected by concentration and doubled to $\sim 350 \mu \mathrm{g} / \mathrm{g}$ in the nanofiber mesh compared to the original 7H240 $(208 \mu \mathrm{g} / \mathrm{g})$ (Figure 1a).

(a)

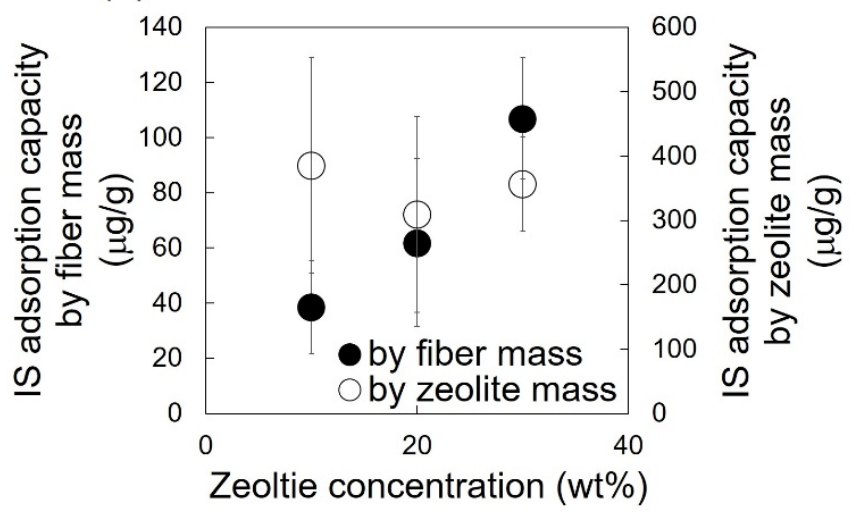

(b)

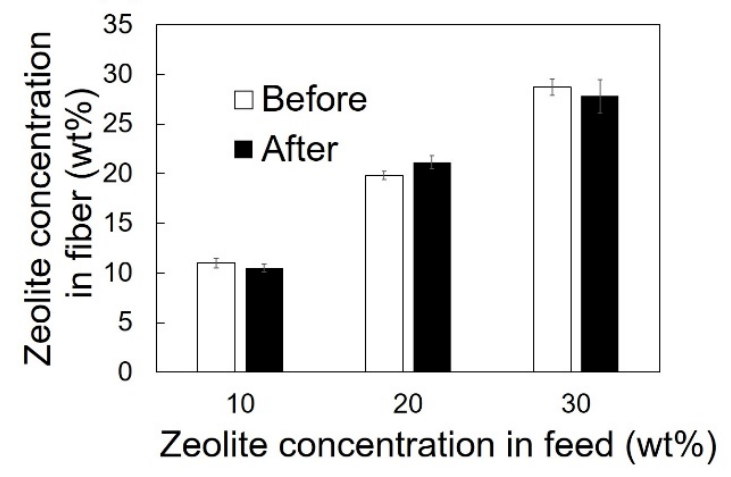

Figure 4. (a) The IS adsorption capacity of 7H240 zeolite/EVOH nanofiber mesh after the adsorption test at $37^{\circ} \mathrm{C}$ for $24 \mathrm{~h}$. The adsorption capacity was calculated by the fiber mass (black circles) and zeolite mass in the nanofiber mesh (white circles) $(n=3)$. (b) The zeolite concentration of the 7H240 zeolite/EVOH nanofiber mesh before and after water immersion test according to TGA $(n=3)$.

TGA analysis of the 7H240 zeolite/EVOH nanofiber mesh was conducted after the IS adsorption test to determine the outflow of zeolite from the nanofiber mesh. There was no significant difference in the zeolite concentrations before and after the adsorption test (Figure $4 \mathrm{~b}$ ), thereby, confirming that zeolite was fixed by the EVOH nanofiber mesh and outflow did not occur after immersion in water for $24 \mathrm{~h}$.

\subsection{Cytotoxic Assay}

The cytotoxicity of the zeolite 7H240 powder was investigated based on the cell viability after incubation with macrophages for $24 \mathrm{~h}$ (Figure S3). Raw 264.7 cells were selected as a model of immune cells in the blood. Although zeolites are thought to be less cytotoxic materials, the cell viability decreased with increasing zeolite 7H240 content, where almost complete cell death occurred at $\sim 8 \mathrm{mg} / 10^{6}$ cells. The cytotoxicity of the plain 
EVOH nanofiber mesh and 7H240 zeolite/EVOH nanofiber mesh was also investigated. No significant cytotoxicity was observed after incubation with macrophages for $24 \mathrm{~h}$, where the cell viability of the $7 \mathrm{H} 240$ zeolite/EVOH nanofiber mesh at a zeolite content of $\sim 1 \mathrm{mg} / 10^{6}$ cells was $96 \%$ (Figure 5). In contrast, $7 \mathrm{H} 240$ powder with the same concentration led to only $86 \%$ cell viability.

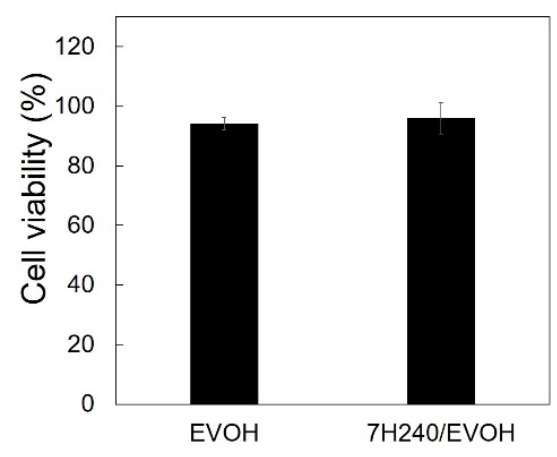

Figure 5. The relative cytotoxicity of the EVOH nanofiber mesh and 7H240 zeolite/EVOH nanofiber mesh in Raw 264.7 cells after incubation at $37^{\circ} \mathrm{C}$ for $24 \mathrm{~h}(n=6)$.

\section{Discussion}

The IS adsorption capacity of bare zeolite increased with their Si/Al ratio. This is because the hydrophobicity of zeolite increased with the $\mathrm{Si} / \mathrm{Al}$ ratio, and thus the benzene ring in IS could interact with the surface of the zeolite more effectively. E. Sarti et al. reported that zeolite with a high $\mathrm{Si} / \mathrm{Al}$ ratio could effectively adsorb toluene, which is a hydrophobic substance, in water [33].

Interestingly, the hydrophobicity achieved at a $\mathrm{Si} / \mathrm{Al}$ ratio of $\sim 240 \mathrm{~mol} / \mathrm{mol}$ was the most suitable for IS adsorption, and a higher $\mathrm{Si} / \mathrm{Al} \mathrm{ratio}$ of $500 \mathrm{~mol} / \mathrm{mol} \mathrm{led} \mathrm{to} \mathrm{a}$ decrease in the adsorption capacity. This is plausibly because the hydrophilicity of a sulfate group or a factor other than $\mathrm{Si} / \mathrm{Al}$ ratio is also important. The effect of pore size was also investigated. We confirmed that a pore size of 6-7 $\AA$ was the best for IS adsorption. According to the study of $\mathrm{V}$. Wernert et al., the calculated molecular size of IS by software is $7.9 \times 1.1 \times 5.4 \AA$ [34]. Since the $\mathrm{x}$ axis size of IS is larger than the pore size of zeolite, IS is considered to adsorb in the direction parallel to $x$ axis as shown in Figure S4.

In addition, zeolites that had a hydrogen ion as the cation adsorbed more IS than those that had a potassium ion. This was due to the larger electrostatic interactions between zeolite and IS. IS ionized in water and had a negative charge. Thus, IS was adsorbed by electrostatic interactions between the cation in the zeolite. In that case, the hydrogen ions have a shorter ionic radius than the potassium ions, and therefore they can make stronger electrostatic interactions. This is the reason why the zeolite with a hydrogen ion adsorbed IS more effectively than those with a potassium ion.

A similar result was reported by Limin Liu et al., where the main factor for IS adsorption was found to be electrostatic interactions [20]. In summary, IS was adsorbed on the zeolite via both hydrophobic and electrostatic interactions. Research reported that these two interactions can work together in aqueous media [35]. Although the immobilization of zeolite into a nanofiber mesh decreased the fiber diameters from 630 to $\sim 450 \mathrm{~nm}$, the diameters were maintained regardless of the zeolite concentration. This was attributed to the use of proportionally less $\mathrm{EVOH}$ polymer to form the nanofibers.

SEM images also demonstrated that the number of zeolite aggregations larger than $20 \mu \mathrm{m}$ increased in the $40 \mathrm{wt} \%$ zeolite concentration. These large aggregations led to the decreasing IS adsorption efficiency due to the lower surface area of zeolite. Therefore, the zeolite $7 \mathrm{H} 240$ concentration of $40 \mathrm{wt} \%$ was removed from further investigation. The TGA result showed that the zeolite $7 \mathrm{H} 240$ was incorporated in the same concentration as the preparation. 
These results confirmed the successful fabrication of a 7H240 zeolite/EVOH nanofiber mesh. It was also indicated that $\mathrm{EVOH}$ can contribute to disperse zeolite particles,and thus the selection of an appropriate concentration of zeolite particles is important to achieve fine fiber formation. In addition, an albumin adsorption test was conducted. Negligible adsorption of albumin on the EVOH was observed after $24 \mathrm{~h}$. This result indicates the longer use of proposed materials in the physiological conditions.

The results of the IS adsorption test showed that the adsorption capacity of IS by $7 \mathrm{H} 240$ zeolite in nanofiber mesh was $\sim 350 \mu \mathrm{g} / \mathrm{g}$. This is larger than the adsorption capacity by the bare $7 \mathrm{H} 240$ zeolite $(208 \mu \mathrm{g} / \mathrm{g})$. This was attributed to increasing the surface area of zeolite $7 \mathrm{H} 240$ via dispersion in the $\mathrm{EVOH}$ nanofiber mesh, while the aggregation of zeolite particles in water resulted in a decrease of the adsorption capacity. The result also means that about $350 \mathrm{~g}$ of zeolite will be required for the decrease of the IS concentration in an adult man to the normal value. The TGA results after the adsorption test confirmed no outflow of zeolite from the nanofiber mesh. This indicates that zeolite was successfully incorporated and immobilized.

The cell viability test revealed that the cytotoxicity of 7H240 zeolite was improved by incorporation into a nanofiber mesh. Specifically, the decrease in cytotoxicity was attributed to the prevention of physical interaction between zeolite 7H240 and cells due to immobilization, and the good biocompatibility of EVOH. Therefore, the 7H240 zeolite/EVOH nanofiber mesh can be useful as a safe and effective alternative of blood purification therapy in future clinical approaches.

\section{Conclusions}

A novel approach to IS adsorption was investigated using zeolite and a zeolite composite nanofiber mesh. Zeolite 7H240 exhibited the highest adsorption capacity due to its optimal Si/Al ratio and was selected for immobilization into an EVOH nanofiber mesh via electrospinning. The zeolite composite nanofiber mesh exhibited a IS adsorption capacity of an $107 \mu \mathrm{g} / \mathrm{g}$, where adsorption capacity of zeolite increased from 208 to $386 \mu \mathrm{g} / \mathrm{g}$ when immobilized in the nanofiber mesh. To decrease the IS concentration of CKD patients to a normal value, about $350 \mathrm{~g}$ of zeolite will be required.

The cell viability improved from $86 \%$ to $96 \%$ before and after immobilization. Therefore, this zeolite composite nanofiber mesh shows potential for use in wearable blood purification devices. A more effective IS adsorption is expected when a zeolite composite nanofiber mesh is used instead of zeolite powder, and further research is underway to continue improving this adsorption capacity. To overcome the limitations of the proposed system, further investigations are also required regarding the mechanical/chemical properties after prolonged use in the blood.

Supplementary Materials: The following are available online at https:/ /www.mdpi.com/article/10 $.3390 /$ fib9060037/s1, Figure S1: IS adsorption capacity of zeolite 7H240 at the different times $(\mathrm{n}=3)$; Figure S2: Albumin concentrations before and after an adsorption test at $37^{\circ} \mathrm{C}$ for $24 \mathrm{~h}(\mathrm{n}=3)$; Figure S3: Cytotoxicity of zeolite 7H240 powder in Raw 264.7 cells after incubation at $37^{\circ} \mathrm{C}$ for $24 \mathrm{~h}$ $(n=6)$; Figure S4: Schematic image of IS adsorption by zeolite.

Author Contributions: Conceptualization, M.S. and M.E.; methodology, M.S. and Y.L.; software, M.S.; validation, Y.L. and M.E.; formal analysis, M.S. and Y.L.; investigation, M.S.; resources, M.E.; data curation, M.S. and Y.L.; writing—original draft preparation, M.S.; writing—review and editing, Y.L. and M.E.; visualization, M.S. and M.E.; supervision, M.E.; project administration, M.E.; funding acquisition, M.E. All authors have read and agreed to the published version of the manuscript.

Funding: This study was also support by JSPS KAKENHI Grant-in-Aid for Scientific Research(B) (JP19H04476) and Grant-in-Aid for Transformative Research Areas(A) (JP20H05877).

Institutional Review Board Statement: Not applicable.

Informed Consent Statement: Not applicable. 
Data Availability Statement: The data that support the findings of this study are available from the corresponding author, M.E., upon reasonable request.

Conflicts of Interest: The authors declare no conflict of interest.

\section{References}

1. Sofue, T.; Nakagawa, N.; Kanda, E.; Nagasu, H.; Matsushita, K.; Nangaku, M.; Maruyama, S.; Wada, T.; Terada, Y.; Yamagata, K.; et al. Prevalence of anemia in patients with chronic kidney disease in Japan: A nationwide, cross-sectional cohort study using data from the Japan Chronic Kidney Disease Database (J-CKD-DB). PLoS ONE 2020, 15, e0236132. [CrossRef]

2. Park, H.; Liu, X.; Henry, L.; Harman, J.; Ross, E.A. Trends in anemia care in non-dialysis-dependent chronic kidney disease (CKD) patients in the United States (2006-2015). BMC Nephrol. 2018, 19, 318. [CrossRef]

3. Mallamaci, F.; Tripepi, G.; D'Arrigo, G.; Borrelli, S.; Garofalo, C.; Stanzione, G.; Provenzano, M.; De Nicola, L.; Conte, G.; Minutolo, R.; et al. Blood pressure variability, mortality, and cardiovascular outcomes in CKD patients. Clin. J. Am. Soc. Nephrol. 2019, 14, 233-240. [CrossRef]

4. Jun, M.; Jardine, M.J.; Perkovic, V.; Pilard, Q.; Billot, L.; Rodgers, A.; Rogers, K.; Gallagher, M. Hyperkalemia and renin-angiotensin aldosterone system inhibitor therapy in chronic kidney disease: A general practice-based, observational study. PLoS ONE 2019, 14, e0213192. [CrossRef] [PubMed]

5. Isakova, T.; Cai, X.; Lee, J.; Xie, D.; Wang, X.; Mehta, R.; Allen, N.B.; Scialla, J.J.; Pencina, M.J.; Anderson, A.H.; et al. Longitudinal FGF23 Trajectories and Mortality in Patients with CKD. J. Am. Soc. Nephrol. 2018, 29, 579-590. [CrossRef] [PubMed]

6. Van Der Made, T.K.; Fedecostante, M.; Scotcher, D.; Rostami-Hodjegan, A.; Sastre Toranõ, J.; Middel, I.; Koster, A.S.; Gerritsen, K.G.; Jankowski, V.; Jankowski, J.; et al. Quantitative Translation of Microfluidic Transporter in Vitro Data to in Vivo Reveals Impaired Albumin-Facilitated Indoxyl Sulfate Secretion in Chronic Kidney Disease. Mol. Pharm. 2019, 16, 4551-4562. [CrossRef] [PubMed]

7. Nishi, K.; Sakurama, K.; Watanabe, H.; Maruyama, T.; Yamasaki, K.; Otagiri, M. Effects of uremic toxins on the binding of aripiprazole to human serum albumin. Biol. Pharm. Bull. 2021, 44, 437-441. [CrossRef] [PubMed]

8. Niwa, T. Role of Indoxyl Sulfate in the Progression of Chronic Kidney Disease and Cardiovascular Disease: Experimental and Clinical Effects of Oral Sorbent AST-120. Ther. Apher. Dial. 2011, 15, 120-124. [CrossRef]

9. Holle, J.; Kirchner, M.; Okun, J.; Bayazit, A.K.; Obrycki, L.; Canpolat, N.; Bulut, I.K.; Azukaitis, K.; Duzova, A.; Ranchin, B.; et al. Serum indoxyl sulfate concentrations associate with progression of chronic kidney disease in children. PLoS ONE 2020, 15, e0240446. [CrossRef] [PubMed]

10. Barreto, F.C.; Barreto, D.V.; Liabeuf, S.; Meert, N.; Glorieux, G.; Temmar, M.; Choukroun, G.; Vanholder, R.; Massy, Z.A. Serum indoxyl sulfate is associated with vascular disease and mortality in chronic kidney disease patients. Clin. J. Am. Soc. Nephrol. 2009, 4, 1551-1558. [CrossRef]

11. Wu, C.J.; Chen, C.Y.; Lai, T.S.; Wu, P.C.; Chuang, C.K.; Sun, F.J.; Liu, H.L.; Chen, H.H.; Yeh, H.I.; Lin, C.S.; et al. The role of indoxyl sulfate in renal anemia in patients with chronic kidney disease. Oncotarget 2017, 8, 83030-83037. [CrossRef] [PubMed]

12. Chen, K.; Horstmeier, S.; Nguyen, V.T.; Wang, B.; Crossley, S.P.; Pham, T.; Gan, Z.; Hung, I.; White, J.L. Structure and Catalytic Characterization of a Second Framework Al(IV) Site in Zeolite Catalysts Revealed by NMR at 35.2 T. J. Am. Chem. Soc. 2020, 142, 7514-7523. [CrossRef] [PubMed]

13. Huang, Z.; Seo, S.; Shin, J.; Wang, B.; Bell, R.G.; Hong, S.B.; Zou, X. 3D-3D topotactic transformation in aluminophosphate molecular sieves and its implication in new zeolite structure generation. Nat. Commun. 2020, 11, 3762. [CrossRef]

14. Zhang, Y.; Chen, Y.; Kang, W.; Han, H.; Song, H.; Zhang, C.; Wang, H.; Yang, X.; Gong, X.; Zhai, C.; et al. Excellent adsorption of $\mathrm{Zn}$ (II) using NaP zeolite adsorbent synthesized from coal fly ash via stage treatment. J. Clean. Prod. 2020, 258, 120736. [CrossRef]

15. Falyouna, O.; Eljamal, O.; Maamoun, I.; Tahara, A.; Sugihara, Y. Magnetic zeolite synthesis for efficient removal of cesium in a lab-scale continuous treatment system. J. Colloid Interface Sci. 2020, 571, 66-79. [CrossRef]

16. Jain, R.; Rimer, J.D. Seed-Assisted zeolite synthesis: The impact of seeding conditions and interzeolite transformations on crystal structure and morphology. Microporous Mesoporous Mater. 2020, 300, 110174. [CrossRef]

17. Quan, Y.; Li, S.; Wang, S.; Li, Z.; Dong, M.; Qin, Z.; Chen, G.; Wei, Z.; Fan, W.; Wang, J. Synthesis of Chainlike ZSM-5 Zeolites: Determination of Synthesis Parameters, Mechanism of Chainlike Morphology Formation, and Their Performance in Selective Adsorption of Xylene Isomers. ACS Appl. Mater. Interfaces 2017, 9, 14899-14910. [CrossRef] [PubMed]

18. Wernert, V.; Schäf, O.; Faure, V.; Brunet, P.; Dou, L.; Berland, Y.; Boulet, P.; Kuchta, B.; Denoyel, R. Adsorption of the uremic toxin p-cresol onto hemodialysis membranes and microporous adsorbent zeolite silicalite. J. Biotechnol. 2006, 123, 164-173. [CrossRef]

19. Ramos-Martinez, V.H.; Ramirez-Vargas, E.; Medellin-Rodriguez, F.J.; Ávila-Orta, C.A.; Gallardo-Vega, C.A.; Jasso-Salcedo, A.B.; Andrade-Guel, M.L. Zeolite 13X modification with gamma-aminobutyric acid (GABA). Microporous Mesoporous Mater. 2020, 295, 109941. [CrossRef]

20. Lu, L.; Yeow, J.T.W. An adsorption study of indoxyl sulfate by zeolites and polyethersulfone-zeolite composite membranes. Mater. Des. 2017, 120, 328-335. [CrossRef]

21. Raharjo, Y.; Fahmi, M.Z.; Wafiroh, S.; Widati, A.A.; Amanda, E.R.; Ismail, A.F.; Othman, M.H.D.; Santoso, D. Incorporation of imprinted-zeolite to polyethersulfone/cellulose acetate membrane for creatinine removal in hemodialysis treatment. J. Teknol. 2019, 3, 137-144. [CrossRef] 
22. Su, Y.L.; Beltsios, K.G.; Cheng, L.P. Phase inversion in reusable baths (PIRBs): A new polymer membrane fabrication method as applied to EVOH. J. Appl. Polym. Sci. 2019, 136, 48193. [CrossRef]

23. Biniaś, D.; Biniaś, W.; Machnicka, A.; Hanus, M. Preparation of antimicrobial fibres from the EVOH/EPC blend containing silver nanoparticles. Polymers 2020, 12, 1827. [CrossRef] [PubMed]

24. Namekawa, K.; Tokoro Schreiber, M.; Aoyagi, T.; Ebara, M. Fabrication of zeolite-polymer composite nanofibers for removal of uremic toxins from kidney failure patients. Biomater. Sci. 2014, 2, 674-679. [CrossRef]

25. Takai, R.; Kurimoto, R.; Nakagawa, Y.; Kotsuchibashi, Y.; Namekawa, K.; Ebara, M. Towards a Rational Design of Zeolite-Polymer Composite Nanofibers for Efficient Adsorption of Creatinine. J. Nanomater. 2016, 2016, 5638905. [CrossRef]

26. Tsuge, M.; Takahashi, K.; Kurimoto, R.; Fulati, A.; Uto, K.; Kikuchi, A.; Ebara, M. Fabrication of water absorbing nanofiber meshes toward an efficient removal of excess water from kidney failure patients. Fibers 2019, 7, 39. [CrossRef]

27. Xue, J.; Wu, T.; Dai, Y.; Xia, Y. Electrospinning and electrospun nanofibers: Methods, materials, and applications. Chem. Rev. 2019, 119, 5298-5415. [CrossRef] [PubMed]

28. Rampichová, M.; Chvojka, J.; Jenčová, V.; Kubíková, T.; Tonar, Z.; Erben, J.; Buzgo, M.; Daňková, J.; Litvinec, A.; Vocetková, K.; et al. The combination of nanofibrous and microfibrous materials for enhancement of cell infiltration and in vivo bone tissue formation. Biomed. Mater. 2018, 13, 025004. [CrossRef]

29. Hou, J.; Yang, J.; Zheng, X.; Wang, M.; Liu, Y.; Yu, D.G. A nanofiber-based drug depot with high drug loading for sustained release. Int. J. Pharm. 2020, 583, 119397. [CrossRef]

30. Zhang, K.; Bai, X.; Yuan, Z.; Cao, X.; Jiao, X.; Li, Y.; Qin, Y.; Wen, Y.; Zhang, X. Layered nanofiber sponge with an improved capacity for promoting blood coagulation and wound healing. Biomaterials 2019, 204, 70-79. [CrossRef]

31. Yu, X.; Shen, L.; Zhu, Y.; Li, X.; Yang, Y.; Wang, X.; Zhu, M.; Hsiao, B.S. High performance thin-film nanofibrous composite hemodialysis membranes with efficient middle-molecule uremic toxin removal. J. Memb. Sci. 2017, 523, 173-184. [CrossRef]

32. Haghdoost, F.; Bahrami, S.H.; Barzin, J.; Ghaee, A. Preparation and characterization of electrospun polyethersulfone/ polyvinylpyrrolidone-zeolite core-shell composite nanofibers for creatinine adsorption. Sep. Purif. Technol. 2021, $257,117881$. [CrossRef]

33. Sarti, E.; Chenet, T.; Pasti, L.; Cavazzini, A.; Rodeghero, E.; Martucci, A. Effect of silica alumina ratio and thermal treatment of beta zeolites on the adsorption of toluene from aqueous solutions. Minerals 2017, 7, 22. [CrossRef]

34. Wernert, V.; Schäf, O.; Ghobarkar, H.; Denoyel, R. Adsorption properties of zeolites for artificial kidney applications. Microporous Mesoporous Mater. 2005, 83, 101-113. [CrossRef]

35. Zhang, L.; Weng, X.; Qu, X.; Fu, H.; Liu, H.; Zheng, S.; Xu, Z.; Zhu, D. Efficient removal of ionic liquids from aqueous media using ZSM-5 zeolites: A tunable mechanism combining micropore filling and electrostatic interaction. Microporous Mesoporous Mater. 2019, 280, 315-323. [CrossRef] 